South African Journal of Geomatics, Vol. 5. No. 3, November 2016

\title{
Geospatial Analyses in Support of Heavy Metal Contamination Assessments of Soil and Grass along Highways at Mafikeng, South Africa
}

\author{
Chris Munyati
}

Department of Geography and Environmental Science, North-West University (Mafikeng Campus), Mmabatho, South Africa, chrismunyati@yahoo.co.uk.

http://dx.doi.org/10.4314/sajg.v5i3.9

\begin{abstract}
Heavy metals in the environment are of concern due to detrimental effects, which include disturbance of plant physiology. This paper presents an exploratory assessment of heavy metal contamination along the main highways in Mafikeng, and illustrates how spatial analyses of the contamination for environmental management purposes can be supported by GIS and Remote Sensing. Roadside soil and grass (Stenotaphrum sp.) samples were analysed for total content per heavy metal. Spatial patterns in soil metal concentrations were evaluated using IDW interpolation. Effects of the contamination on the vigour of roadside grass were assessed using NDVI transects within 30 m of the roads, on a pan-sharpened $5 \mathrm{~m}$ resolution SPOT 5 HRG multispectral image. The results showed that NDVI values increased with distance from roads $\left(R^{2} 0.508-0.965 ; p<0.05\right)$, indicating that proximity to roads reduced grass vigour. Metal concentrations in grass tissue were lower than in soil by an average factor of nine, but varied as the soil concentrations. The concentrations of the heavy metals that are associated with motor vehicles along roads were in the order $[\mathrm{Fe}]>[\mathrm{Mn}]>[\mathrm{Zn}]>[\mathrm{Pb}]>[\mathrm{Ni}]>[\mathrm{Cu}]>[\mathrm{Cr}]>[\mathrm{Cd}]$, but were much lower than in cities that have higher motor vehicle traffic. IDW interpolation of metal concentrations revealed trafficrelated spatial variations that can support environmental management. In this limestone mineralogy soil the relative abundance of Mn (range $2.4-11.4 m g / k g$ ) is attributable to lead replacement fuels that are in use, while the Pb concentrations (range 0.20-1.29mg/kg) indicate persistence of $\mathrm{Pb}$ in the urban environment some ten years after the phasing out of leaded petrol.
\end{abstract}

\section{Introduction}

Heavy metals in the environment, particularly as contributed by human activity in urban areas, are of concern globally because of their negative effects on environmental quality and human health. A number of studies globally highlight the concern about heavy metals (e.g. Loranger \& Zayed, 1994; Binning \& Baird, 2001; Lee et al., 2006; Islam et al., 2015; Maanan et al., 2015; Pons-Branchu et al., 2015). Heavy metals bio-accumulate, then their concentrations bio-magnify along the food chain, and can eventually end up in human food (Martin \& Griswold, 2009). They can cause the destruction of soil microbiota, as well as decline or even death of the aboveground plants through physiological disturbances (Perfus-Barbeoch et al., 2002; Viard et al., 2004). A 
number of heavy metals are detrimental to human health (Martin \& Griswold, 2009). For example, $\mathrm{Pb}$ causes neurological problems (Kovarik, 2005), $\mathrm{Cd}$ and $\mathrm{Ni}$ cause genomic problems (Coen et al., 2001). Quantifying the concentrations of heavy metals in the urban environment, therefore, contributes to assessments of environmental quality.

One of the sources of heavy metals is motor vehicles. Motor vehicle-sourced heavy metals enter the food chain through the soil, from which they are taken up by plants (Galal \& Shehata, 2015). Therefore, vegetation and soil in the vicinity of roads in urban areas are vulnerable to heavy metal contamination (Lytle et al., 1995; Garcia \& Millan, 1998), although in soils heavy metals can occur naturally as derived from the parent rock minerals. The heavy metals that have been associated with motor vehicles as source along roads are mainly $\mathrm{Cd}, \mathrm{Cr}, \mathrm{Cu}, \mathrm{Fe}, \mathrm{Mn}, \mathrm{Ni}, \mathrm{Pb}$ and $\mathrm{Zn}$ (Lough et al., 2005; Huber et al., 2016). To a lesser extent other metals like Al, As, Ba, Be, Co, Hg, Sb, Se, and V have been linked to motor vehicles in literature. Heavy metal contamination from motor vehicles along roads occurs through exhaust fumes $(\mathrm{Cr}, \mathrm{Cu}, \mathrm{Fe}, \mathrm{Mn}, \mathrm{Ni}, \mathrm{Pb}, \mathrm{Zn})$, brake $(\mathrm{Cd}, \mathrm{Pb}, \mathrm{Zn})$ and tyre rubber $(\mathrm{Mn}, \mathrm{Pb})$ wear. The contamination from exhaust fumes can occur up to $320 \mathrm{~m}$ from highways, with the maximum contamination between 5 and 20m (Viard et al., 2004). Additionally surface runoff can wash the heavy metals from the vicinity of roads into water courses. Some heavy metals, such as $\mathrm{Cu}, \mathrm{Mn}$, and $\mathrm{Zn}$, are essential as plant nutrients (Nada Kumar et al., 1995). There are, however, critical thresholds beyond which the metals become toxic to plants, for example $125 \mathrm{mg} / \mathrm{kg}$ for $\mathrm{Cu} ; 400 \mathrm{mg} / \mathrm{kg}$ for Zn (Garcia \& Millan, 1998). Cadmium (Cd) toxicity, for example, causes plant wilting (Perfus-Barbeoch et al., 2002).

Leaded fuel gradually began to be phased out globally, largely as a result of the detrimental effects of $\mathrm{Pb}$ (Nriagu, 1990). Alternative lead replacement fuels are being used instead, which contain other heavy metals like Mn (Geivanidis et al., 2003). South Africa achieved the total phasing out of leaded fuels in 2006. Roadside pollution is not the sole source of heavy metals but it contributes to the country's heavy metal contamination problem in water courses, water being a scarce resource in South Africa. Studies have highlighted detrimental effects of heavy metals on aquatic organisms in terrestrial water bodies in South Africa (e.g. Van Aardt \& Erdmann, 2004; Retief et al., 2006). The metals have also been detected in estuaries and the coastal marine environment (Binning \& Baird, 2001; Jackson et al., 2005; Bosch et al., 2016).

Given the spatially limited nature of observations obtained from soil sampling, spatial interpolation in a Geographic Information System (GIS) can establish continuous surface patterns in heavy metal contamination (e.g. Cicchella et al., 2008). Spatial interpolation in a GIS estimates values of a variable based on those determined at sampling points. The result is a raster (pixel) layer showing a continuous surface of values in the variable, from which spatial patterns can be established. There are a number of interpolation algorithms, one of the most widely used in soil analyses being the Inverse Distance Weighted (IDW) interpolator (Kravchenko, 2003; Robinson \& Metternicht, 2006). The IDW equation is given as (Roberts et al., 2004):

$$
Z_{\left(x_{0}\right)}=\sum_{i=1}^{n} \lambda_{i} Z_{\left(x_{i}\right)}
$$


where $Z_{\left(x_{o}\right)}$ is the estimated (unknown) value, $Z_{\left(x_{i}\right)}$ is the sample (known) value; and $\lambda_{i}$ is the weighting value, which is quantified as (Roberts et al., 2004):

$$
\lambda_{i}=\left[d_{\left(x_{i}, x_{0}\right)}\right]^{p} / \sum_{i=1}^{n}\left[d_{\left(x_{i}, x_{0}\right)}\right]^{p}
$$

where $d_{\left(x_{i}, x_{o}\right)}$ is the Euclidean distance between locations $x_{i}$ and $x_{o}$, and $p$ is a power value. The results of IDW interpolation will vary depending on the selection of the power value and the neighbourhood search strategy (Watson \& Philip, 1985; Roberts et al., 2004). The power parameter ( $p$ in Equation 2) enables control of the significance of sample point values on the interpolated values based on their distance from the predicted point. With a higher power value more emphasis can be put on the nearest sample points and, thus, nearby data will have the most influence; and the resulting interpolated surface will have more detail (i.e. will be less smooth) (Watson \& Philip, 1985).

Imagery from Remote Sensing, on the other hand, is useful in assessing vegetation vigour as affected by heavy metal contamination, using the Normalised Difference Vegetation Index (NDVI). The NDVI is a numerical indicator of vegetation vigour that makes use of the near infrared (NIR) and red $(R)$ reflectance as in Equation 3 (Lillesand et al., 2014).

$$
N D V I=\frac{N I R-r e d}{N I R+r e d}
$$

For a sensor that has NIR and $R$ bands the NDVI values that result from Equation 1 range between -1 and +1 , pixels with vigorous vegetation having positive values close to +1 (Lillesand et al., 2014). Therefore, the more vigorous the vegetation is the higher the NDVI value. Under similar environmental conditions vegetation that is subjected to heavy metal contamination is, therefore, expected to have lower NDVI values than contamination-free vegetation due to the effects of heavy metals on plant physiology (Liu et al., 2010). Thus, Boluda et al. (1993) established strong correlations between NDVI values derived from Landsat 5 TM bands (NIR, Red) and available Cd, $\mathrm{Cu}, \mathrm{Ni}, \mathrm{Pb}$ and $\mathrm{Zn}$ in soil.

This paper presents an exploratory assessment of the concentrations of heavy metals in roadside soil and grass at Mafikeng, South Africa (Figure 1a), and illustrates potential roles of GIS and Remote Sensing analyses in support of the assessment. Being a rural town in a developing country, and without routine monitoring of the problem by the authorities, the hypothesis was that the soils and grass along the highways in Mafikeng were highly contaminated by heavy metals. Soil and grass samples were collected from the vicinity of the main highways in Mafikeng. The concentration of heavy metals in the samples was determined in the laboratory. Spatial patterns in the concentration of heavy metal concentrations in the soil were established using a spatial 
interpolation algorithm in a GIS. The NDVI was used in assessing change in grass vigour with distance from the main highways.

(a)
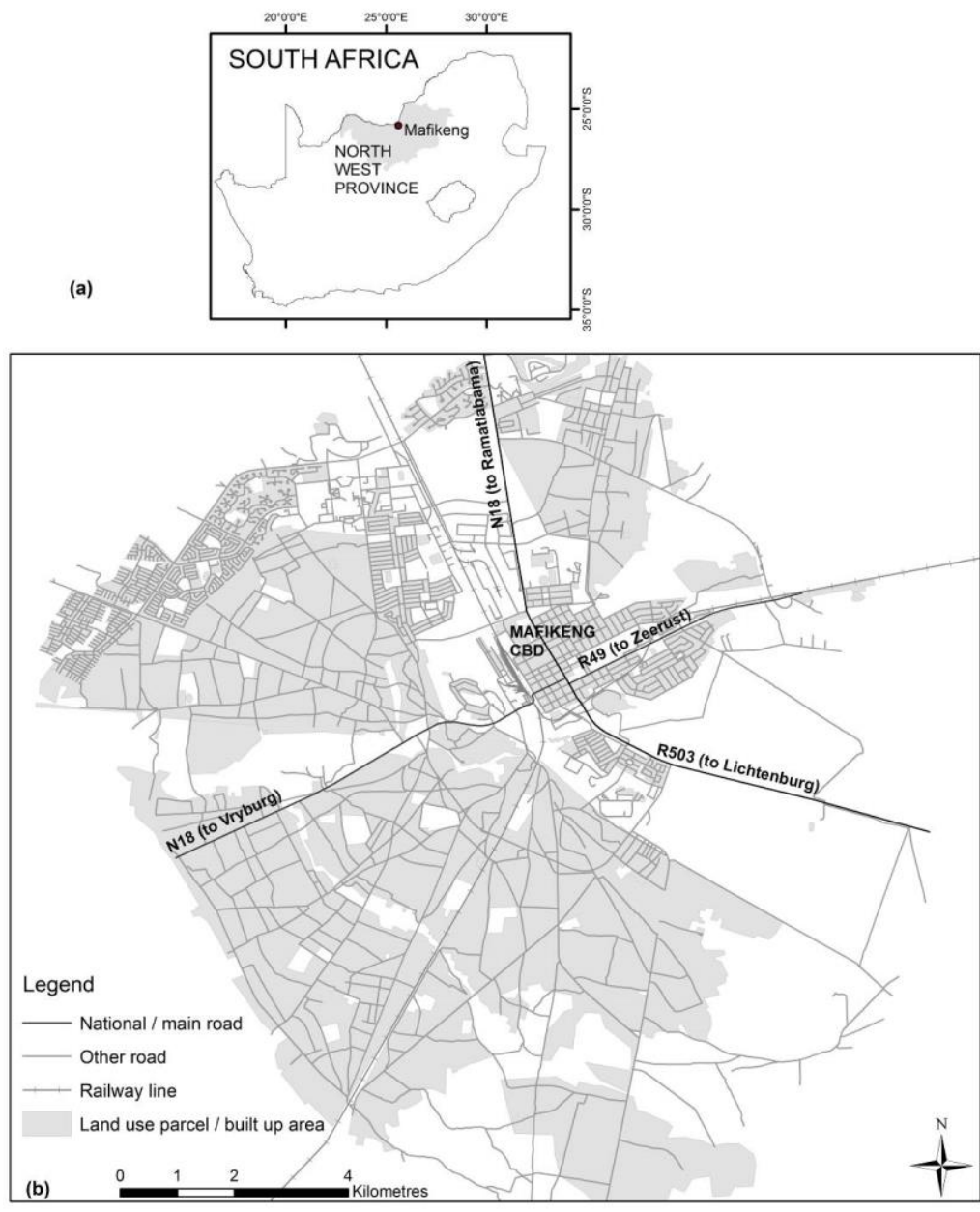

Figure 1. Location of Mafikeng in South Africa (a), and (b) the road network in Mafikeng town

\section{Material and Methods}

\subsection{Study area}

Mafikeng is located in the North West Province of South Africa (Figure 1a) and is the administrative capital of the province. There are four main road inlets for motor vehicle traffic from other towns into Mafikeng: the N18 North to Ramatlabama and then West to Vryburg, the R49 to Zeerust and the R503 to Lichtenburg, all of which converge in the Central Business District, CBD (Figure 1b).

The N18 North (to Ramatlabama) is also an international route, as one of the gateways from South Africa into the neighbouring country of Botswana. The R49 and R503 lead eastwards towards the economic hub of South Africa, Gauteng Province. Therefore, these roads handle international and inter-province traffic through Mafikeng in addition to the local traffic. In 2006 the N18 North was expanded from one to two opposite traffic lanes. In the context of this study these 
road improvements are significant since they disturbed the accumulated heavy metals on the soil surface along the highway.

There is a distinct rain season in the study area, starting in October and ending in April in the following year. The geology is predominantly limestone, which consists of calcite $\left(\mathrm{CaCO}_{3}\right)$ and aragonite - $(\mathrm{Ca}, \mathrm{Sr}, \mathrm{Pb}, \mathrm{Zn}) \mathrm{CO}_{3}$, and the soils are petric calcisols.

\subsection{Soil and plant sampling}

For the analysis of heavy metal content in soil and plants, only the four major roads into Mafikeng were used since these highways handle larger traffic volumes than the suburban roads. Soil samples were collected at sampling points that were approximately $20 \mathrm{~m}$ from the roadside and at intervals of $0.5-1 \mathrm{~km}$ along the roads (depending on land use obstacles), avoiding the paved roadsides of the CBD (Figure 2a). The soil samples were collected from the $0-10 \mathrm{~cm}$ depth range, using a soil auger. The coordinates of each sampling point were captured using a Garmin eTrex GPS that had location accuracy of ${ }_{ \pm} 3 \mathrm{~m}$.

At each sampling point a sample of grass tissue (leaves, stems) was also collected. For consistency the same species of grass was used, a Stenotaphrum sp. grass (Figure 2a, inset photo). All samples were then taken to the laboratory for analysis of heavy metal content. The samples were collected in April 2015, a largely rain free period. Both the soil and grass samples were airdried in the laboratory for a week.

\subsection{Laboratory analysis}

The soil and grass samples underwent acid sequence digestion in the laboratory prior to analysis for heavy metal content. The dried soil samples were disaggregated using a pestle and mortar and a $2 \mathrm{~mm}$ sieve was then used to remove large particles. From each sample $1 \mathrm{~g}$ of soil was placed into a reaction vessel in which $3 \mathrm{ml}$ of $55 \%$ Nitric Acid $\left(\mathrm{HNO}_{3}\right)$ and $9 \mathrm{ml}$ of $32 \%$ Hydrochloric Acid $(\mathrm{HCl})$ were added, respectively.

The grass samples were crushed using a pestle and mortar. From each sample $1 \mathrm{~g}$ of crushed grass was placed in a crucible, and the crucible and grass placed in a furnace at $800^{\circ} \mathrm{C}$ for 16 hours to be ashed. For the digestion process, each sample was placed into a reaction vessel in which $8 \mathrm{ml}$ of 55\% Nitric Acid and $2 \mathrm{ml}$ of $32 \%$ Hydrochloric Acid were added, respectively.

The soil or grass sample mixture was then digested for 45 minutes in an Anton Paar Multiwave 3000 Multiwave Reaction System, and then transferred to a distilled water-rinsed 100ml flask in which it was left to stand overnight to allow sediments to settle at the bottom. The mixture was then filtered into a centrifuge tube and then analysed for a suite of 25 metal elements using an ICP-OES (Inductively Coupled Plasma-Optical Emission Spectrometer), in triplicates from which average values were recorded. Therefore, in addition to heavy metals that are associated with motor vehicle traffic along roads $(\mathrm{Cd}, \mathrm{Cr}, \mathrm{Cu}, \mathrm{Fe}, \mathrm{Mn}, \mathrm{Ni}, \mathrm{Pb}, \mathrm{Zn})$, the concentrations of a number of other metal elements was determined from the samples. Total content per metal was determined, as opposed to dissolved or plant available content in the case of soil samples. 


\subsection{GIS interpolation of roadside heavy metal concentration in soils}

For the interpolation of heavy metal concentrations from the roadside samples the Inverse Distance Weighted (IDW) interpolator was selected. IDW interpolation works well with 'noisy' data and is best suited to moderately dense sampling with regard to local variation, as was the case in this study (Figure 2a).

ArcMap 10.3 was employed for the spatial interpolation of the soil heavy metal concentrations, using data from the sampling sites in Figure 2a. The interpolation was restricted to within $30 \mathrm{~m}$ of the roads, by generating a 30m buffer using the Buffer Analysis tool in ArcMap 10.3. Limiting the interpolation to $30 \mathrm{~m}$ was necessary because during field work it was observed that this was the maximum width of building-free space away from some of the roads.

An output cell size of $5 \mathrm{~m}$ was set. The power value ( $p$ in Equation 2) was set to 3, and the search radius was limited to two sample points. These power value and search radius settings were selected in order to limit the contribution by distant sampling sites in the interpolation of heavy metal concentration data values. This was because the heavy metal pollution was perceived as highly variable among the four highways, as well as between sampling points along the same highway.

\subsection{Remote sensing of impacts of heavy metals on grass vigour}

Two SPOT 5 (Systéme Pour l'Observation de la Terre 5) High Resolution Geometric (HRG) images of the area (scene reference K/J 128/402) acquired on 5 March 2013 (peak rain season) were obtained from the South African National Space Agency. They were a 5m-resolution panchromatic image (sensitive in the $0.48-0.71 \mu \mathrm{m}$ range) and a $10 \mathrm{~m}$-resolution multispectral image (sensitivity in green; $0.50-0.59 \mu \mathrm{m}$, red; $0.61-0.68 \mu \mathrm{m}$, and near infrared; $0.78-0.89 \mu \mathrm{m}$ ). The peak rain season date of the image meant that the vegetation was at near peak vigour, which facilitated analysis of effects on its vigour by heavy metals. The vegetation along the highways is predominantly grass.

Using ERDAS Imagine 2015 software the 10m spatial resolution of the multispectral image was enhanced to $5 \mathrm{~m}$ by pan-sharpening it with the $5 \mathrm{~m}$ panchromatic image. The technique of pansharpening uses a high spatial resolution panchromatic image to improve the spatial resolution of a multispectral image. In the process the resolution merge technique was employed.

Pan-sharpening helped improve the spatial resolution to make it suitable for comparison with the more detailed sampling data. The resulting multispectral image enabled the analysis of vegetation vigour at the higher spatial resolution of $5 \mathrm{~m}$ compared to the original lower resolution of $10 \mathrm{~m}$. The pan-sharpened image was then projected to the UTM projection (zone 35S, WGS84 datum). An NDVI image (see Equation 3) was then generated from the pan-sharpened image. 


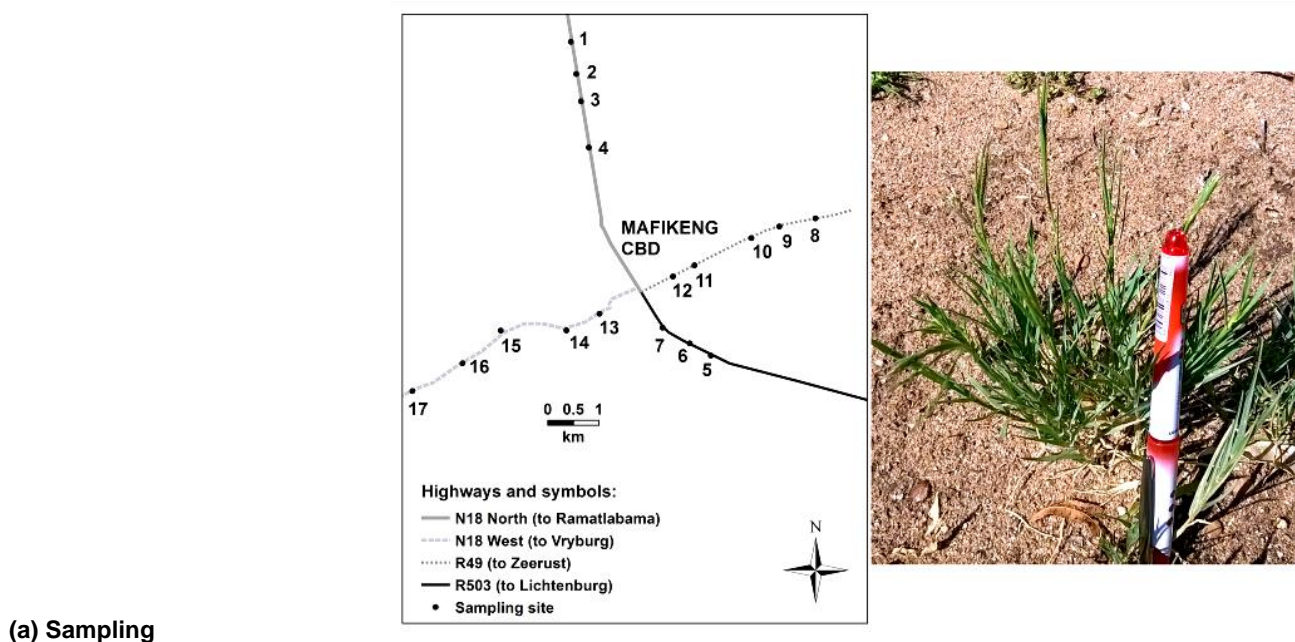

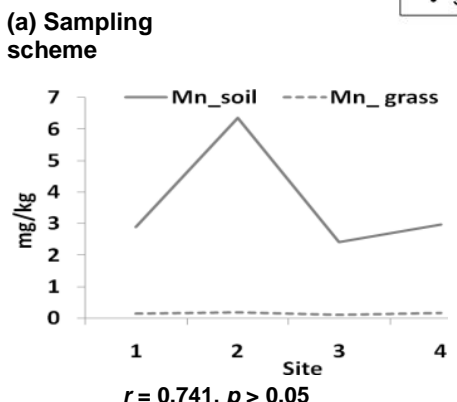

(b) Highway N18 North

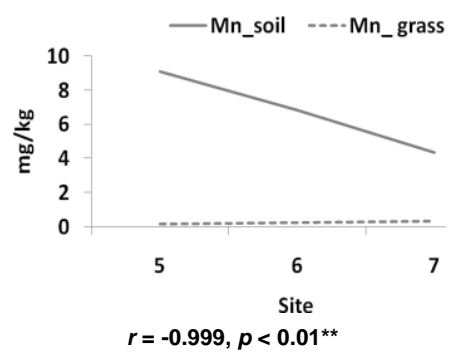

(c) Highway R503

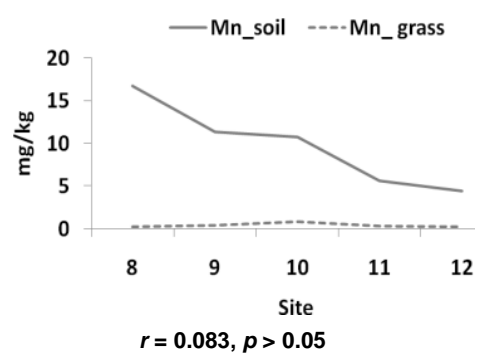

(d) Highway R49

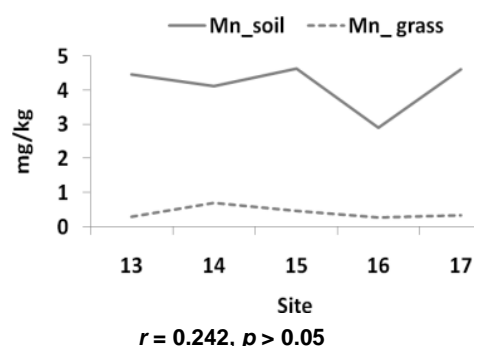

(e) Highway N18 West
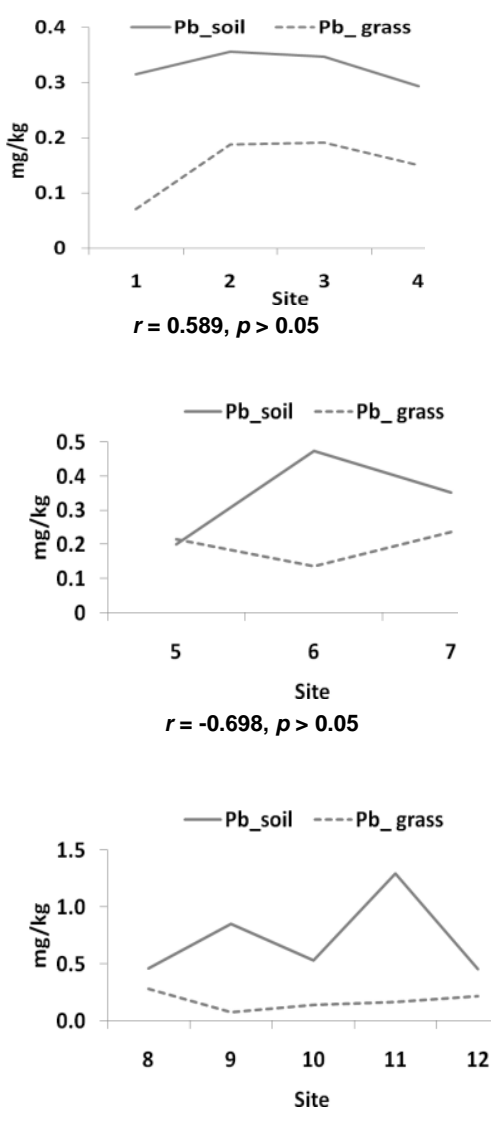

$r=-0.473, p>0.05$
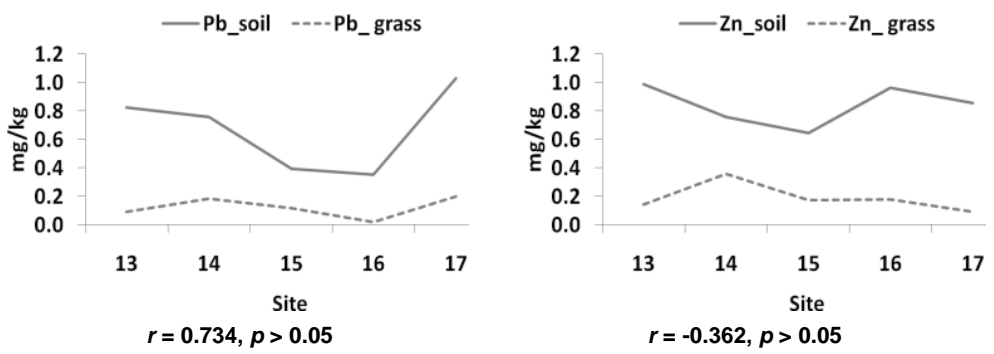

Figure 2. Sample site layout (a), and ((b)-(e)) concentration of selected heavy metals ( $\mathrm{Mn}, \mathrm{Pb}, \mathrm{Zn})$ in soil and grass at the numbered sampling sites in (a) along the four main highways of the study area (correlation coefficient, $r$, and probability, $p$, values indicated below each graph). The inset photo in (a) shows the Stenotaphrum sp. grass that was sampled 
The concentration of heavy metals has been shown to reduce away from the roadside (Lytle et al., 1995; Garcia \& Millan, 1998; Galal \& Shehata, 2015). Therefore, the change in NDVI values along transects radiating away from the highways was analysed in order to assess the effect of traffic-sourced heavy metals on grass vigour. These transects were perpendicular to the roads, and on one side only since that were rarely roadside locations that were buildings-free on both sides. They were restricted to a length of $30 \mathrm{~m}$ (i.e. 6 pixels on the pan-sharpened image) due to the presence of buildings beyond $30 \mathrm{~m}$ from some of the highways.

The NDVI values for each $5 \mathrm{~m}$ pixel along the $30 \mathrm{~m}$ respective transects were obtained, and then statistically analysed for relationship with distance from the roadside (source of heavy metal pollution) using regression analysis. This analysis was not performed for transects at sampling points 9, 10, 14, 15, 16 and 17 (Figure 2a) due to the existence of buildings within 10m of the roads.

\section{Results}

\subsection{Heavy metal concentrations in soil and grass}

For the same metal element there were variations in concentration along a given highway (e.g. Figure $2 \mathrm{~b}-\mathrm{e}$ ), attributable to site specific factors such as proximity to highway runoff drainage canals. Table 1 shows the mean metal concentrations that were determined from the soil and grass samples. The very high $\mathrm{Ca}$ concentrations are reflective of the limestone underlying geology at Mafikeng. For the majority of the metals the concentration was higher in the soil than in grass at a given sampling point; the average was 9 times the concentration in grass tissue. The exceptions were $\mathrm{K}, \mathrm{Na}$ and $\mathrm{Sb}$, whose concentrations were higher in the grass tissue than in the soil (Table 1).

The metal concentrations in grass tissue varied as the soil concentrations, though largely with statistically non significant associations. This suggests that heavy metal concentrations in soils can be used to infer concentrations in grass tissue. This association is illustrated in Figure 2b-e for Mn, $\mathrm{Pb}$ and $\mathrm{Zn}$. The three metals were selected for the illustrations in Figure $2 \mathrm{~b}$-e because Mn occurs in lead replacement fuels, and $\mathrm{Pb}$ and $\mathrm{Zn}$ can occur as part of limestone's mineral aragonite ( $(\mathrm{Ca}, \mathrm{Sr}$, $\mathrm{Pb}, \mathrm{Zn}) \mathrm{CO}_{3}$ ). $\mathrm{Ca}$ and $\mathrm{Sr}$, which can occur in aragonite, were excluded from the illustrations because the two metals are not associated with motor vehicles along roads. A possible reason for the low correlation between concentration values of the soil and the plants is leaching to deeper layers in the soil, as well as soil erosion. Both leaching and soil erosion could have resulted in low concentration values in the soil, while plant tissue had accumulated levels of the metals, resulting in low correlation.

In the soil the concentrations of the motor vehicle related heavy metals $\mathrm{Cd}, \mathrm{Cr}, \mathrm{Cu}, \mathrm{Fe}, \mathrm{Mn}, \mathrm{Ni}$, $\mathrm{Pb}$ and $\mathrm{Zn}$ were in the order $[\mathrm{Fe}]>[\mathrm{Mn}]>[\mathrm{Zn}]>[\mathrm{Pb}]>[\mathrm{Ni}]>[\mathrm{Cu}]>[\mathrm{Cr}]>[\mathrm{Cd}]$. For $\mathrm{Cd}, \mathrm{Cr}, \mathrm{Cu}, \mathrm{Mn}, \mathrm{Ni}$, $\mathrm{Pb}$, and $\mathrm{Zn}$ the concentrations were well below the standards set by the Department of Environmental Affairs in South Africa (Table 1). Next to zero concentrations of Cd were detected in grass tissue, indicating that there was no Cd toxicity in this grass species. 


\subsection{Spatial patterns in roadside heavy metal concentration in soils}

Of the heavy metals that are associated with motor vehicles, the differences in mean concentrations of $\mathrm{Cd}, \mathrm{Cu}, \mathrm{Mn}, \mathrm{Ni}, \mathrm{Pb}$ and $\mathrm{Zn}$ were statistically significant between at least two highways (Table 2). For these metals the resulting IDW interpolations in Figure 3 show a pattern of higher heavy metal contamination along the highways in the south eastern sector of Mafikeng. The recently expanded N18 North highway had significantly lower $\mathrm{Cd}$ and Ni concentrations than the $\mathrm{R} 503$ in the south, and significantly lower concentrations of $\mathrm{Cd}, \mathrm{Cu}, \mathrm{Mn}, \mathrm{Ni}$, and $\mathrm{Pb}$ than highway R49 in the south east. The R49 also had a statistically significant higher mean concentration of $\mathrm{Pb}$ than the R503, and higher $\mathrm{Cu}$ and Ni concentrations than the N18 West. The R503 had significantly higher concentrations of $\mathrm{Pb}$ and $\mathrm{Zn}$ than the N18 West.

The R49 highway had the highest concentrations of $\mathrm{Cd}, \mathrm{Cu}, \mathrm{Mn}, \mathrm{Ni}$, and $\mathrm{Pb}$ (Table 1), indicating that it had the most severe contamination by heavy metals. The second most contaminated was the R503 highway. The interpolated spatial patterns in Figure 3 depict these differences in levels of contamination, showing the R49 to have had the highest $\mathrm{Cd}, \mathrm{Cu}, \mathrm{Mn}, \mathrm{Ni}, \mathrm{Pb}$ and that the R503 had high $\mathrm{Cd}, \mathrm{Cu}$ and Ni contamination. Both the R49 and R503 have high usage by traffic to and from Gauteng Province, South Africa's economic hub.

\subsection{Effects of heavy metals on plant vigour}

The multispectral SPOT image of Mafikeng and its resulting NDVI image are shown in Figure 4. For six out of the eleven transects that were analysed, there were strong and statistically significant $(p<0.05)$ relationships between grass vigour as indicated by NDVI values and distance away from the roads. Figure 5 illustrates the change in NDVI values with distance from the highways for transects that yielded statistically significant relationships, and shows that NDVI values increased with distance from the roadside. The $R^{2}$ values for the statistically significant relationships ranged between 0.508 (transect from point 7 in Figure 4b) and 0.965 (transect from point 6 in Figure 4b). Further indication that the heavy metals influenced the vigour of the grass is shown in Figure 6 in which NDVI values are plotted against grass tissue concentrations, for metals whose variations showed a direct relationship between soil and grass concentrations. [Pb] in particular influenced the NDVI (Figures 6a, c), though with a non-significant correlation $(p>0.05)$. However for [Zn] the correlation with NDVI values was statistically significant $(r=0.958, p<0.05$; Figure $6 \mathrm{~b})$.

\section{Discussion and conclusion}

The results provide evidence that there is heavy metal contamination along the roads in the study area. The contamination appeared to be related to traffic volumes, as indicated by the interpolated spatial patterns. The two south eastern highways that had higher contamination of $\mathrm{Cd}, \mathrm{Cu}, \mathrm{Mn}, \mathrm{Ni}$, and $\mathrm{Pb}$ (Figure 3) are the main inlets from the economic hub of the country, to the east. The high usage of these roads, for freight and passenger transport, accounts for the heavy metal contamination. The results also indicate some detrimental effects of the heavy metal contamination on vegetation along the highways, and that concentrations of heavy metals in soil may be used to infer the concentrations in grass tissue, depending on the grass species. 
South African Journal of Geomatics, Vol. 5. No. 3, November 2016

Table 1. Mean metal concentration values $(\mathrm{mg} / \mathrm{kg}$ ) along the four main highways in Mafikeng, from soil and grass samples at the sites in Figure 2a.

Metal elements that are associated with motor vehicles along roads are highlighted.

\begin{tabular}{|c|c|c|c|c|c|c|c|c|c|c|c|}
\hline \multirow[t]{2}{*}{ Metal_sample } & \multicolumn{4}{|c|}{ Highway } & \multirow[t]{2}{*}{ SSV* } & \multirow[t]{2}{*}{ Metal_sample } & \multicolumn{4}{|c|}{ Highway } & \multirow[t]{2}{*}{$\mathbf{S S V}^{*}$} \\
\hline & N18 North & R503 & R49 & N18 West & & & N18 North & R503 & R49 & N18 West & \\
\hline Al_soil & 68.05 & 59.94 & 66.13 & 67.57 & & Mg_soil & 65.48 & 42.33 & 44.86 & 37.92 & \\
\hline Al_grass & 2.54 & 5.41 & 8.34 & 4.18 & & Mg_grass & 8.09 & 14.46 & 13.56 & 16.12 & \\
\hline As_soil & 0.45 & 0.83 & 0.55 & 0.33 & 5.8 & Mn_soil & 3.65 & 6.74 & 9.80 & 4.15 & 740 \\
\hline As_grass & 0.38 & 0.50 & 0.05 & 0.06 & & Mn_grass & 0.15 & 0.25 & 0.41 & 0.42 & \\
\hline Ba_soil & 0.68 & 1.33 & 1.61 & 0.83 & & Mo_soil & 0.08 & 0.08 & 0.07 & 0.06 & \\
\hline Ba_grass & 0.07 & 0.10 & 0.15 & 0.13 & & Mo_grass & 0.05 & 0.03 & 0.06 & 0.04 & \\
\hline Be_soil & 0.00 & 0.00 & 0.00 & 0.00 & & Na_soil & 0.01 & 0.03 & 0.00 & 0.01 & \\
\hline Be_grass & 0.00 & 0.00 & 0.00 & 0.00 & & $\mathrm{Na}$ _grass & 1.07 & 0.70 & 4.99 & 5.22 & \\
\hline Ca_soil & 354.92 & 663.83 & 209.82 & 357.10 & & Ni_soil & 0.27 & 0.53 & 0.59 & 0.31 & 91 \\
\hline Ca_grass & 44.21 & 50.36 & 56.57 & 61.00 & & Ni_grass & 0.04 & 0.03 & 0.06 & 0.08 & \\
\hline Cd_soil & 0.01 & 0.04 & 0.05 & 0.02 & 7.5 & Pb_soil & 0.33 & 0.34 & 0.72 & 0.67 & 20 \\
\hline Cd_grass & 0.00 & 0.00 & 0.00 & 0.00 & & $\mathrm{~Pb}$ _grass & 0.15 & 0.20 & 0.18 & 0.12 & \\
\hline Co_soil & 0.07 & 0.23 & 0.28 & 0.11 & 300 & Sb_soil & 0.18 & 0.23 & 0.13 & 0.16 & \\
\hline Co_grass & 0.00 & 0.00 & 0.00 & 0.01 & & $\mathrm{Sb}$ _grass & 0.23 & 0.09 & 0.18 & 0.17 & \\
\hline Cr_soil & 0.41 & 0.27 & 0.34 & 0.41 & 6.5 & Se_soil & 0.40 & 0.10 & 0.00 & 0.00 & \\
\hline Cr_grass & 0.03 & 0.02 & 0.07 & 0.04 & & Se_grass & 0.00 & 0.00 & 0.00 & 0.00 & \\
\hline Cu_soil & 0.24 & 0.45 & 0.52 & 0.23 & 16 & Sr_soil & 0.22 & 0.21 & 0.17 & 0.22 & \\
\hline $\mathrm{Cu}$ _grass & 0.03 & 0.04 & 0.06 & 0.06 & & Sr_grass & 0.08 & 0.11 & 0.14 & 0.13 & \\
\hline Fe_soil & 232.12 & 254.79 & 286.04 & 252.66 & & Tl_soil & 0.03 & 0.07 & 0.02 & 0.02 & \\
\hline Fe_grass & 4.41 & 5.84 & 9.28 & 5.52 & & Tl_grass & 0.03 & 0.04 & 0.04 & 0.05 & \\
\hline K_soil & 17.78 & 19.59 & 18.50 & 17.42 & & V_soil & 0.16 & 0.21 & 0.27 & 0.22 & 150 \\
\hline K_grass & 27.76 & 29.71 & 40.82 & 26.51 & & V_grass & 0.01 & 0.03 & 0.02 & 0.03 & \\
\hline Li_soil & 0.04 & 0.01 & 0.02 & 0.05 & & Zn_soil & 0.71 & 0.66 & 0.93 & 0.84 & 240 \\
\hline Li_grass & 0.00 & 0.01 & 0.01 & 0.16 & & $\mathrm{Zn \_ grass}$ & 0.26 & 0.15 & 0.30 & 0.19 & \\
\hline
\end{tabular}

*SSV = Soil Screening Value: a South African standard set for human and ecosystem health (Department of Environmental Affairs, 2012). 


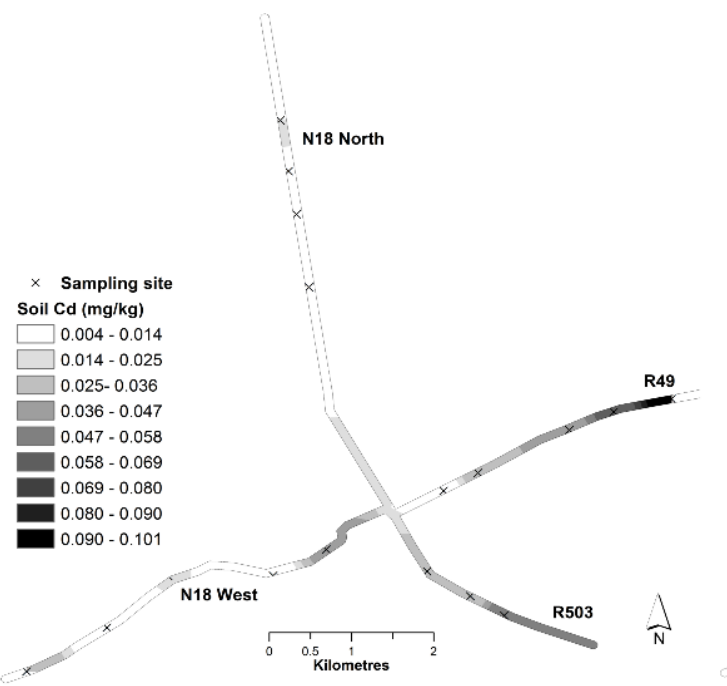

(a) Cadmium (Cd)

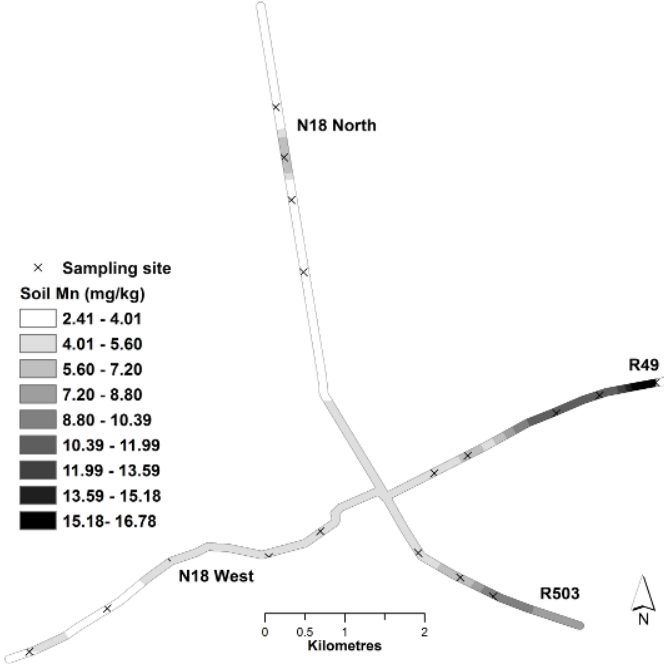

(d) Manganese (Mn)

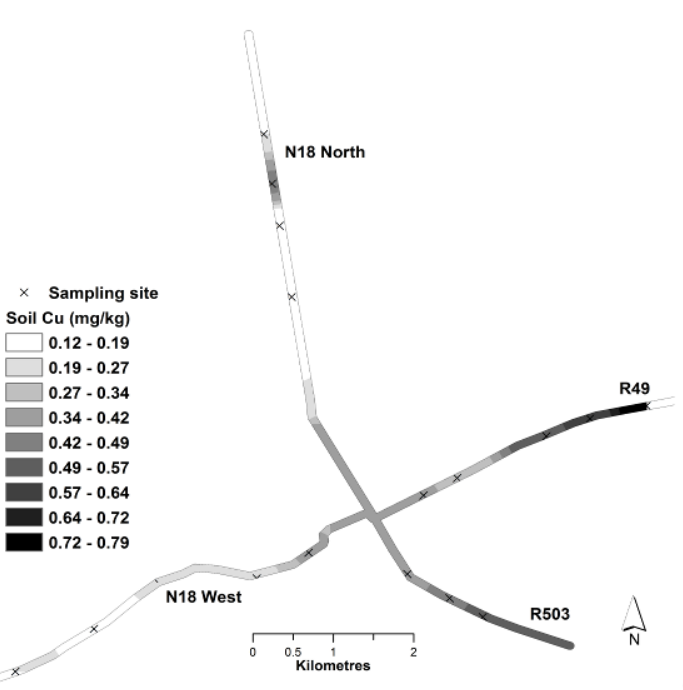

(b) Copper $(\mathrm{Cu})$

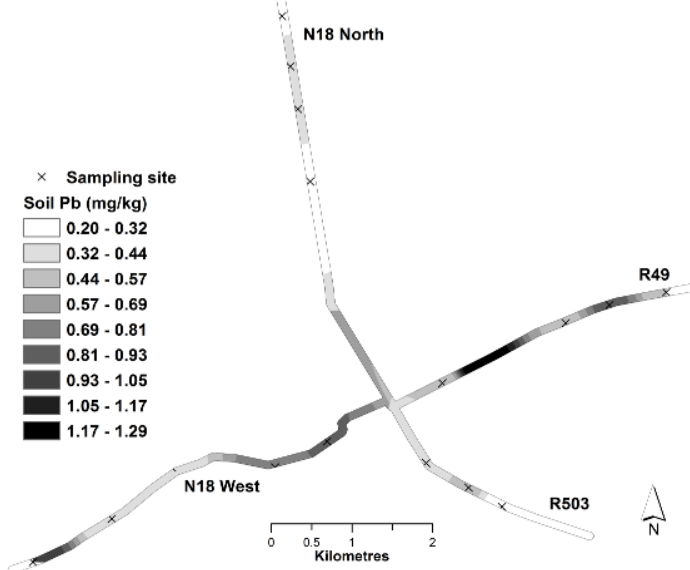

(c) Lead (Pb)

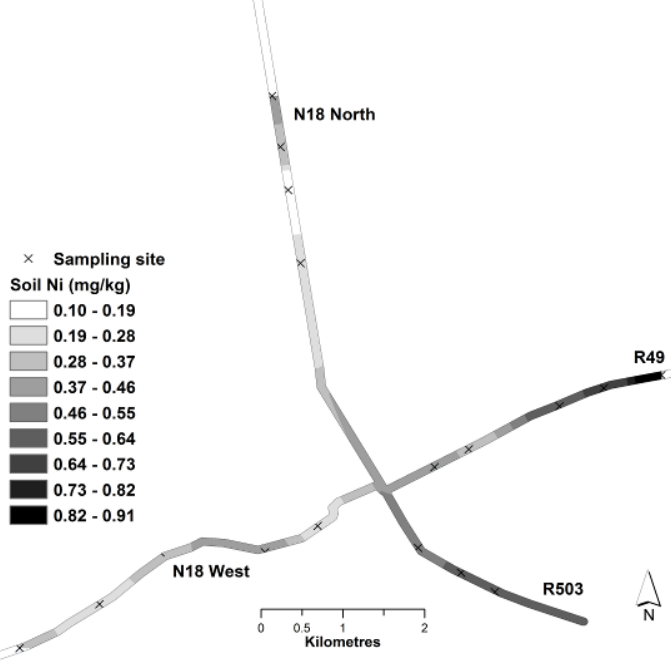

(e) Nickel (Ni)

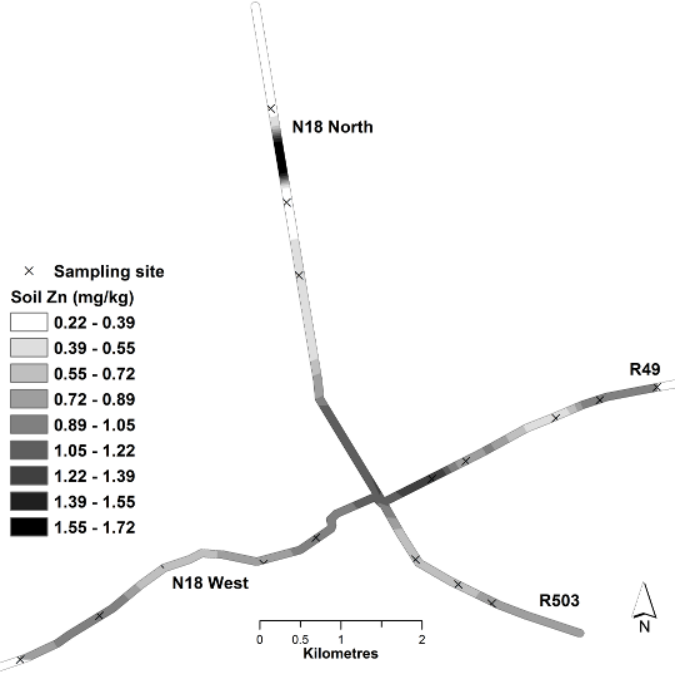

(f) Zinc (Zn)

Figure 3. Spatial patterns in concentrations of $\mathrm{Cd}, \mathrm{Cu}, \mathrm{Mn}, \mathrm{Ni}, \mathrm{Pb}$ and $\mathrm{Zn}$ in soil within $30 \mathrm{~m}$ of the four main highways at Mafikeng, based on IDW interpolation of concentrations from the sampling sites shown in Figure 2a 


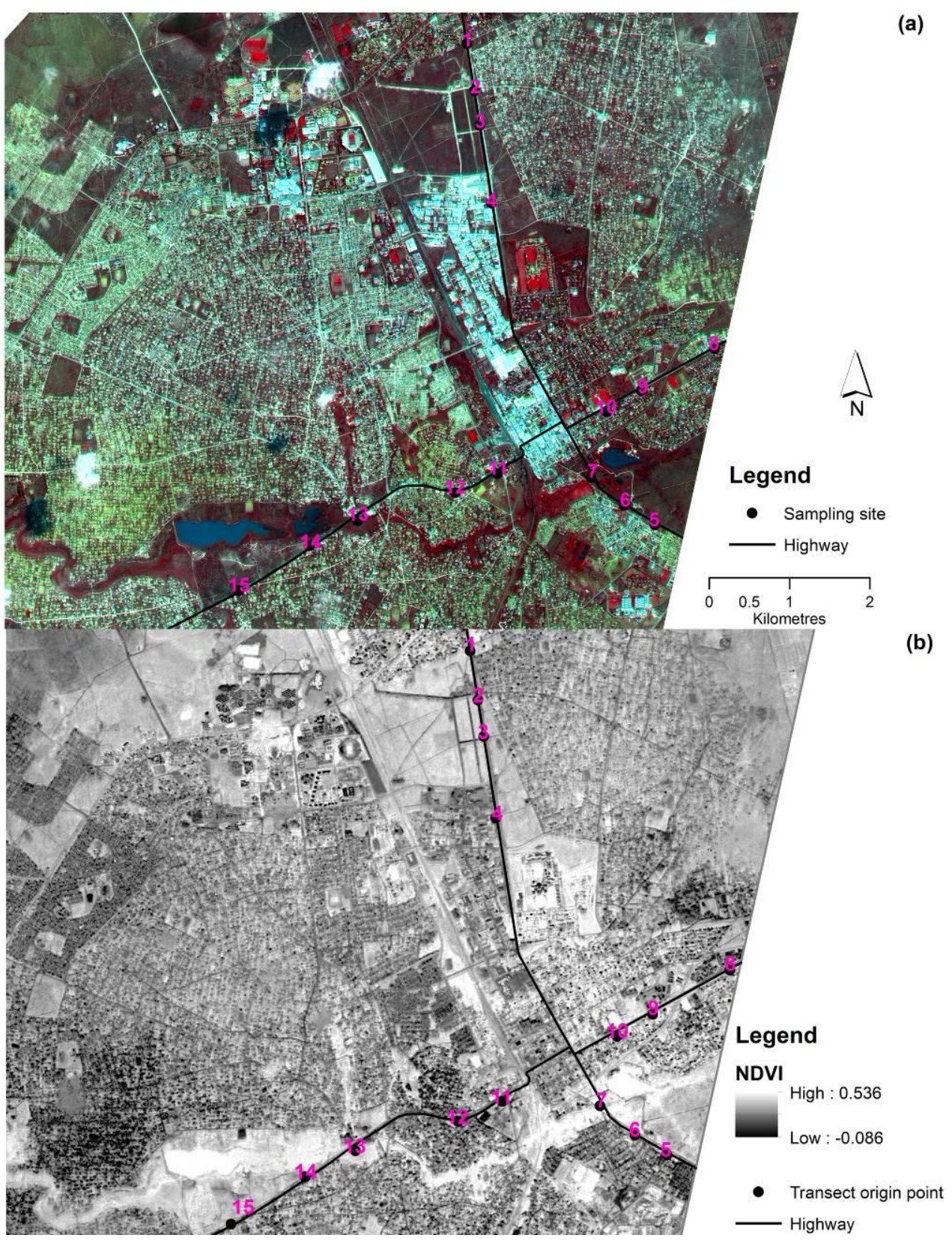

Figure 4. The pan-sharpened SPOT 5 HRG image of Mafikeng town (RGB:321) (a), and its resulting NDVI image (b). In both (a) and (b) the sampling sites (as in Figure 2a) that served as roadside origin points for NDVI profile transects (Figure 5) are indicated and numbered, their symbol sizes exaggerated for visibility

The concentration of $\mathrm{Mn}$ in soil along the highways was generally higher than $\mathrm{Pb}$ (Table 1). The [Mn] range was $2.4-11.4 \mathrm{mg} / \mathrm{kg}$, while $[\mathrm{Pb}]$ ranged $0.20-1.29 \mathrm{mg} / \mathrm{kg}$. The higher $[\mathrm{Mn}]$ in the high traffic use south eastern sector highways can be attributed to the lead replacement fuels that are in use, given the limestone geology that is naturally $\mathrm{Mn}$-free. Despite the aragonite $((\mathrm{Ca}, \mathrm{Sr}, \mathrm{Pb}$, $\mathrm{Zn}) \mathrm{CO}_{3}$ ) mineralogy of limestone that can contain $\mathrm{Pb}$, there were spatial variations in $[\mathrm{Pb}$ ] (Figure 3 , Table 1). This indicates motor vehicle sourced $\mathrm{Pb}$ which has persisted in the environment some ten years after the phasing out of leaded petrol. There were, however, no historical records against which to compare the current levels of heavy metal contamination along these highways. 
Table 2. Matrix of statistically significant $(p<0.05)$ differences in mean metal concentrations between highways, based on the student's $t$ test (for metals indicated in bold)

\begin{tabular}{|c|c|c|c|c|}
\hline \multirow{5}{*}{ 离 } & & \multicolumn{3}{|c|}{ Highway (see Figure 2a) } \\
\hline & & N18 North & R503 & R49 \\
\hline & R503 & $\begin{array}{l}\text { Cd: } t=3.30, p=0.023 \\
\mathbf{N i}: t=0.368, p=0.01\end{array}$ & & \\
\hline & $\mathrm{R} 49$ & $\begin{array}{l}\text { Cd: } t=2.28, p=0.042 \\
\text { Cu: } t=2.47, p=0.021 \\
\text { Mn: } t=2.566, p=0.025 \\
\text { Ni: } t=2.80, \mathrm{p}=0.01 \\
\text { Pb: } t=2.402, p=0.037\end{array}$ & $\mathbf{P b}: t=2.08, p=0.04$ & \\
\hline & N18 West & & $\begin{array}{l}\mathbf{N i}: t=5.15, p=0.001 \\
\mathbf{P b}: t=2.15, p=0.04 \\
\mathbf{Z n}: t=2.14, p=0.04\end{array}$ & $\begin{array}{l}\mathbf{C u}: t=2.92, p=0.016 \\
\mathbf{N i}: t=2.80, p=0.02\end{array}$ \\
\hline
\end{tabular}

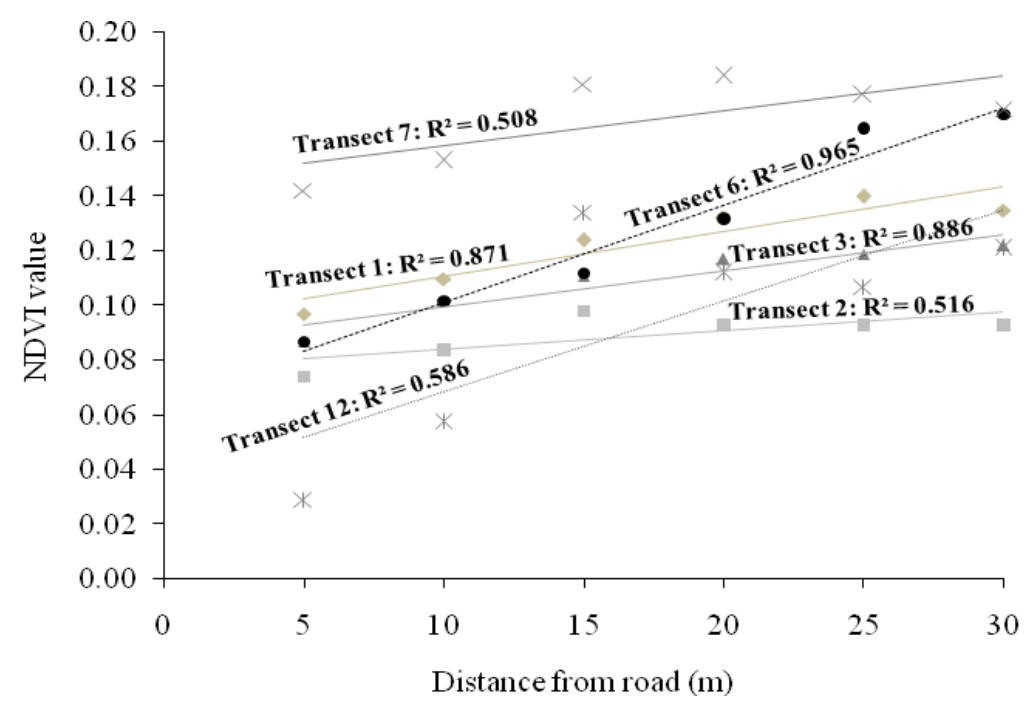

Figure 5. Statistically significant relationships between distance from roads (heavy metal source) and NDVI values from the SPOT image in Figure $4 \mathrm{~b}$, along $5 \mathrm{~m}$ pixel transects originating at the labelled sampling points in Figure 4

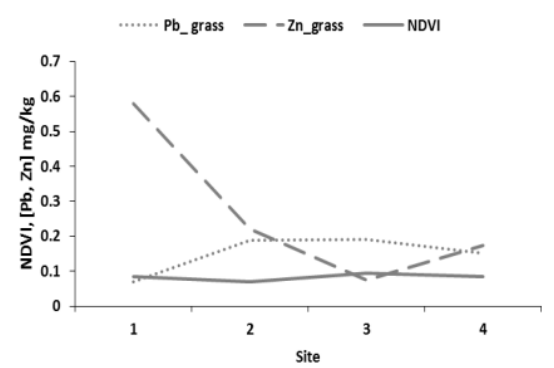

NDVI versus $[\mathrm{Pb}], r=-0.015, p>0.05$

(a)

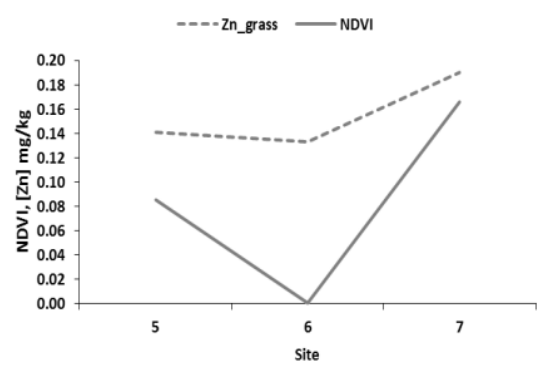

NDVI versus $[\mathrm{Zn}], r=0.958, p<0.05^{*}$

(b)

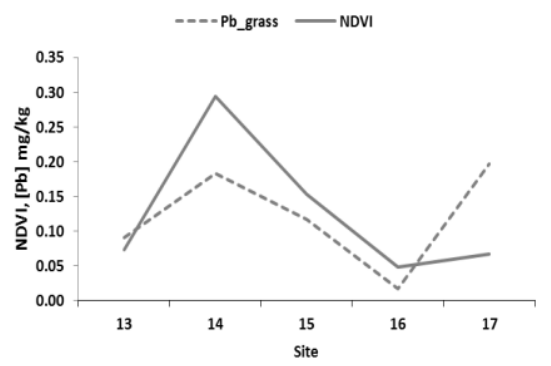

NDVI versus $[\mathrm{Pb}], r=0.522, p>0.05$

(c)

Figure 6. Relationship between NDVI values and heavy metal concentrations in grass tissue for the metals in Figure 2 whose concentrations in grass tissue varied as the soil concentrations 
The concentrations of the heavy metals that are associated with motor vehicles $(\mathrm{Cd}, \mathrm{Cr}, \mathrm{Cu}, \mathrm{Fe}$, $\mathrm{Mn}, \mathrm{Ni}, \mathrm{Pb}$ and $\mathrm{Zn}$ ) were much lower in Mafikeng than those reported in comparative studies in cities that have higher motor vehicle traffic (e.g. Lytle et al., 1995; Garcia \& Millan, 1998; Viard et al., 2004; Lee et al., 2006; Huber et al., 2016). In the absence of official traffic census annual average daily traffic (AADT) data, traffic counts were made in June 2015 during peak hour at fixed points on Mafikeng's main highways. The highest traffic frequency was 1200 vehicles per hour. If this peak hour traffic frequency was maintained for 24 hours it would amount to an AADT value of 28800 vehicles per day. However, the actual AADT value is considerably less since peak hour volumes are not maintained for 24 hours. Therefore, the traffic frequency at Mafikeng is quite low compared to more developed countries with AADT values of over 15000 vehicles per day.

The concentrations of the heavy metals were also well below the standards set by the Department of Environmental Affairs in South Africa (Table 1). This indicates acceptable environmental quality at the time of this study, as affected by heavy metal pollution along highways. It is perhaps unexpected, for a developing country context. However, the cumulative effect of bioaccumulation along the food chain could be detrimental in terms of plant toxicity in the long term. The current levels of contamination could be the beginning of a higher pollution levels. The Molopo River drains through the Mafikeng area, and it is quite possible that negative impacts in the aquatic ecosystem could result from heavy metals being washed by surface runoff into the river. In a river whose catchment is just east of the Molopo's head waters, Van Aardt \& Erdmann (2004) reported $\mathrm{Cd}, \mathrm{Cu}, \mathrm{Pb}$ and $\mathrm{Zn}$ concentrations in fish. In the predominantly agriculture area of Mafikeng meat livestock graze near the highways, and could accumulate the heavy metals in their organs. Therefore, in addition to ecosystem effects the heavy metal contamination threatens human health and food security.

Routine monitoring of heavy metal contamination along the highways by the local authorities is recommended. At the time of this study no routine monitoring was being conducted by the local authorities at Mafikeng. Time series analyses using imagery of higher spatial resolution than that used in this study would be a useful component of the routine monitoring. The imagery can include the $0.5 \mathrm{~m}$ resolution aerial imagery that is occasionally acquired and is available at the National Geo-Spatial Information (NGI) in Cape Town. As demonstrated in this study GIS and Remote Sensing analyses can be useful in support of the monitoring, through indicating the spatial patterns of the contamination and the effects of vegetation, respectively.

\section{Acknowledgements}

Refilwe Matsie, then a postgraduate student at North-West University at the time of this study, is gratefully acknowledged for assistance with the analysis of the samples in the laboratory. Funding for field work was obtained from North-West University under the Food Security and Safety Research Niche Area. Mogomotsi Moeng and Emmanuel Ndive, also postgraduates at North-West University at the time of this study, are gratefully acknowledged for assisting with field sampling. 
Part of this paper (minus metal concentration data and GIS interpolation) was presented at the 2015 Geomatics Indaba conference, Kempton Park, South Africa.

\section{References}

Binning, K \& Baird, D 2001, 'Survey of heavy metals in the sediments of the Swartkops River Estuary, Port Elizabeth South Africa', Water SA, vol. 27, no. 4, pp. 461-466.

Boluda, R, Andreu, PV, Gilabert, MA \& Sobrino, P 1993, 'Relation between reflectance of rice crop and indices of pollution by heavy metals in soils of Albufera National Park (Valencia, Spain)', Soil Technology, vol. 6, no. 4, pp. 351-363.

Bosch, AC, O'Neill, B, Sigge, GO, Kerwath, SE \& Hoffman, LC 2016, 'Heavy metal accumulation and toxicity in smoothhound (Mustelus mustelus) shark from Langebaan Lagoon, South Africa', Food Chemistry, vol. 190, pp. 871-878.

Cicchella, D, De Vivo, B, Lima, A, Albanese, S, McGill, RAR \& Parrish, RR 2008, 'Heavy metal pollution and $\mathrm{Pb}$ isotopes in urban soils of Napoli, Italy', Geochemistry: Exploration Environment Analysis, vol. 8, no. 1, pp. 103-112.

Coen, N, Mothersill, C, Kadhim, M \& Wright, EG 2001, 'Heavy metals of relevance to human health induce genomic instability', The Journal of Pathology, vol. 195, no. 3, pp. 293-299.

Department of Environmental Affairs 2012, 'National Environmental Management Waste Act 2008: Draft National Norms and Standards for the Remediation of Contaminated Land and Soil Quality', Government Gazette No. 35160, Government of the Republic of South Africa, Pretoria.

Facchinelli, A, Sacchi, E \& Mallen, L 2001, 'Multivariate statistical and GIS-based approach to identify heavy metal sources in soils', Environmental Pollution, vol. 114, no.3, pp. 313-324.

Galal, TM \& Shehata, HS 2015, 'Bioaccumulation and translocation of heavy metals by Plantago major L. grown in contaminated soils under the effect of traffic pollution', Ecological Indicators, vol. 48, pp. 244251.

Garcia, R \& Millan, E 1998, 'Assessment of $\mathrm{Cd}, \mathrm{Pb}$ and $\mathrm{Zn}$ contamination in roadside soils and grasses from Gipuzkoa (Spain)', Chemosphere, vol. 37, no. 8, pp. 1615-1625.

Geivanidis, S, Pistikopoulos, P \& Samaras, Z 2003, 'Effect on exhaust emissions by the use of methylcyclopentadienyl manganese tricarbonyl (MMT) fuel additive and other lead replacement gasolines', Science of the Total Environment, vol. 305, no. 1, pp. 129-141.

Huber, M, Welker, A \& Helmreich, B 2016, 'Critical review of heavy metal pollution of traffic area runoff: Occurrence, influencing factors, and partitioning', Science of the Total Environment, vol. 541, pp. 895919.

Islam, MS, Ahmed, MK, Raknuzzaman, M, Habibullah-Al-Mamun, M \& Islam, MK 2015, 'Heavy metal pollution in surface water and sediment: A preliminary assessment of an urban river in a developing country', Ecological Indicators, vol. 48, pp. 282-291.

Jackson, RN, Baird, D \& Els, S 2005, 'The effect of the heavy metals lead $\left(\mathrm{Pb}^{2+)}\right.$ and zinc $\left(\mathrm{Zn}^{2+)}\right.$ on the brood and larval development of the burrowing crustacean, Callianassa kraussi', Water SA, vol. 31, no.1, pp. 107-116.

Kovarik, W 2005, 'Ethyl-leaded gasoline: How a classic occupational disease became an international public health disaster', International Journal of Occupational and Environmental Health, vol. 11, no. 4, pp. 384397.

Kravchenko, AN 2003, 'Influence of spatial structure on accuracy of interpolation methods', Soil Science Society of America Journal, vol. 67, no. 5, pp. 1564-1571.

Lee, CSL, Li, X, Shi, W, Cheung, SCN \& Thornton, I 2006, 'Metal contamination in urban, suburban, and country park soils of Hong Kong: A study based on GIS and multivariate statistics', Science of the Total Environment, vol. 356, no. 1, pp. 45-61. 
Lillesand, TM, Kiefer, RW \& Chipman, JW 2014, Remote sensing and image interpretation, $7^{\text {th }}$ edition, Wiley, New York.

Liu, M, Liu, X, Li, M, Fang, M \& Chi, W 2010, 'Neural-network model for estimating leaf chlorophyll concentration in rice under stress from heavy metals using four spectral indices', Biosystems Engineering, vol. 106, no. 3, pp. 223-233.

Loranger, S \& Zayed, J 1994, 'Manganese and lead concentrations in ambient air and emission rates from unleaded and leaded gasoline between 1981 and 1992 in Canada: A comparative study', Atmospheric Environment, vol. 28, no. 9, pp. 1645-1651.

Lough, GC, Schauer, JJ, Park, JS, Shafer, MM, DeMinter, JT \& Weinstein, JP 2005, 'Emissions of metals associated with motor vehicle roadways', Environmental Science \& Technology, vol. 39, no. 3, pp. 826836.

Lytle, CM, Smith, BN \& McKinnon, CZ 1995, 'Manganese accumulation along Utah roadways: A possible indication of motor vehicle exhaust pollution', Science of the Total Environment, vol. 162, no. 2, pp. 105109.

Maanan, M, Saddik, M, Maanan, M, Chaibi, M, Assobhei, O \& Zourarah, B 2015, 'Environmental and ecological risk assessment of heavy metals in sediments of Nador lagoon, Morocco', Ecological Indicators, vol. 48, pp. 616-626.

Martin, S \& Griswold, W 2009, 'Human health effects of heavy metals', Environmental Science and Technology briefs for citizens, vol. 15, pp. 1-6.

Nada Kumar, PBA, Dushenkov, V, Motto, H \& Raskin, I 1995, 'Phyotoextraction: The use of plants to remove heavy metals from soils', Environmental Science \& Technology, vol. 29, no. 5, pp. 1232-1238.

Nriagu, JO 1990, 'The rise and fall of leaded gasoline', Science of the Total Environment, vol. 92, pp. 13-28.

Perfus-Barbeoch, L, Leonhardt, N, Vavasseur, A \& Forestier, C 2002, 'Heavy metal toxicity: Cadmium permeates through calcium channels and disturbs the plant water status', The Plant Journal, vol. 32, no. 4, pp. 539-548.

Pons-Branchu, E, Ayrault, S, Roy-Barman, M, Bordier, L, Borst, W, Branchu, P, Douville, E \& Dumont, E 2015, 'Three centuries of heavy metal pollution in Paris (France) recorded by urban speleothems', Science of the Total Environment, vol. 518, pp. 86-96.

Retief, NR, Avenant-Oldewage, A \& Du Preez, H 2006, 'The use of cestode parasites from the largemouth yellowfish, Labeobarbus kimberleyensis (Gilchrist and Thompson, 1913) in the Vaal Dam, South Africa as indicators of heavy metal bioaccumulation', Physics and Chemistry of the Earth, Parts $A / B / C$, vol. 31, no. 15 , pp. $840-847$.

Roberts, EA, Sheley, RL \& Lawrence, RL 2004, 'Using sampling and inverse distance weighted modelling for mapping invasive plants', Western North American Naturalist, vol. 64, pp. 312-323.

Robinson, TP \& Metternicht, G 2006, 'Testing the performance of spatial interpolation techniques for mapping soil properties', Computers and Electronics in Agriculture, vol. 50, no. 2, pp. 97-108.

Van Aardt, WJ \& Erdmann, R 2004, 'Heavy metals (Cd, Pb, Cu, Zn) in mudfish and sediments from three hard-water dams of the Mooi River catchment, South Africa', Water SA, vol. 30, no. 2, pp. 211-218.

Viard, B, Pihan, F, Promeyrat, S \& Pihan, J-C 2004, 'Integrated assessment of heavy metal ( $\mathrm{Pb}, \mathrm{Zn}, \mathrm{Cd})$ highway pollution: bioaccumulation in soil, Graminaceae and land snails', Chemosphere, vol. 55, no. 10, pp. 1349-1359.

Watson, DF \& Philip, GM 1985, ‘A refinement of Inverse Distance Weighted interpolation', Geoprocessing, vol. 2, pp. 315-327. 